\title{
Microbial and enzyme analysis of soil after the agricultural utilization of biogas digestate and mineral mining waste
}

\author{
K. Różyło ${ }^{1}$. J. Bohacz²
}

Received: 2 April 2019 / Revised: 14 August 2019 / Accepted: 27 August 2019 / Published online: 31 August 2019

(C) The Author(s) 2019

\begin{abstract}
The intensity of organic matter transformation in soil may be subject to various factors, especially to the previously applied non-standard chemical-based fertilizers. The objective of study was to assess the number of selected groups of microorganisms and enzymatic activity in soil after waste utilization. Biogas digestate (1.5 and 3.0\%) and mineral mining waste (10 and 20\%) were added to podzolic soil. The results demonstrated that the application of these wastes increased the number of microorganisms in the soil. $20 \%$ mineral mining waste provided the most favorable conditions for the development of oligotrophs and copiotrophs, whereas $3 \%$ biogas digestate most positively affected the total number of bacteria. This waste increased soil enzyme activity proportionally to the applied concentration. The highest activity was obtained for 1.5\% biogas digestate. The number of oligotrophs, copiotrophs, and proteolytic microorganisms correlated positively with $\mathrm{pH}$, organic carbon content, total nitrogen, and micronutrients present in the soil, while negatively with phosphorus content. The activity of the majority of enzymes was positively correlated with the content of mineral nitrogen, phosphorus, and potassium. In this study, we were not able to demonstrate a negative correlation between the content of heavy metals and the number of microorganisms in the soil. These results suggest that biogas digestate and mineral mining waste can be used in agricultural practice to improve microbial activity of the subsoil with a large reserve of safety for the soil environment.
\end{abstract}

Keywords Enzymatic activity $\cdot$ Heavy metals bioavailability $\cdot$ Ionic balance $\cdot$ Microorganism tolerance $\cdot$ Toxins immobilization

\section{Introduction}

In Europe, the number of biogas installations is increasing, which enables the possibility of recycling biomass on a large scale combined with the production of renewable energy. In 2016, the amount of energy produced from farm biogas, co-digestion biogas, and industrial biogas installations in the European Union (EU) was more than 187.2 GWh (16.1 Mtoe) (Navigant Research and EurObserv'ER). It is

Editorial responsibility: Parveen Fatemeh Rupani.

J. Bohacz

justyna.bohacz@up.lublin.pl

1 Department of Agricultural Ecology, Faculty of Agrobioengineering, University of Life Sciences in Lublin, Akademicka 13 Street, 20-950 Lublin, Poland

2 Laboratory of Mycology, Department of Environmental Microbiology, Faculty of Agrobioengineering, University of Life Sciences in Lublin, Leszczynskiego 7 Street, 20-069 Lublin, Poland estimated that in 2022, the global production of biogas will be around 383.8 GWh per year (Raboni et al. 2015, based on Navigant Research and EurObserv'ER). However, biogas installations do not eliminate the problem of biowaste completely, as the process of fermentation results in the formation of, apart from methane, biogas digestate (BD), also classified as biowaste, which, when not used, may constitute an environmental hazard. One of the potential directions of $\mathrm{BD}$ use is its application in agriculture for soil and plant fertilization.

The current research has demonstrated that BD is a specific type of organic matter (OM), which, when added to the soil, improves its physicochemical properties. Compared with nondigested organic materials, BD increases the content of organic carbon and reduces the rate of its transformation (thereby stabilizing OM) in soil (Lopedota et al. 2013). Moreover, it contains high amounts of mineral nitrogen (MN) (60-70\% total nitrogen (TN)) compared with organic fertilizers (e.g., compost and cattle manure-which contain around 6-30\% of TN) (Svensson et al. 2004; Alburquerque 
et al. 2012). BD applied to the soil at appropriate concentrations has been shown to be nontoxic toward some of the most significant groups of microorganisms as evidenced by ecotoxicological testing (Różyło et al. 2015; Stefaniuk et al. 2015).

Another way of research to improve the properties of light soils can be the utilization of mining mineral waste (MS) in the form of loamy rocks, including carboniferous rocks originating from the extractive industry. Loamy rocks possess high absorption capacity for chemical compounds and minerals (Jabłońska 2012). Introduction of such rocks to light podzolic soils (PSs) has a structure-forming effect, which enhances the size, distribution, and pore density, thus increasing the amount of aeration in the soil. It also increases the net surface area of soil particles, water, and nutrient retention capacity of the soil. Depending on the composition of loamy rocks, they may either increase the minerals content in the soil or may increase their availability directly or indirectly by changing the $\mathrm{pH}$ of the soil (Mader et al. 1997).

Both BD and MS contain huge amounts of OM (total organic carbon (TOC) at 35.6-63.3\% DW and $28.1 \%$ DW, respectively) (Stefaniuk et al. 2015, Różyło et al. 2017). In addition to improving the physicochemical properties of the soil, OM also stimulates the growth of the microorganisms and increases the enzymatic activity of the soil. The fertility of the soil in the natural agroecosystem depends on the microbial processes such as mineralization of organic nitrogen $(\mathrm{N})$, carbon $(\mathrm{C})$, sulfur $(\mathrm{S})$, and phosphorus $(\mathrm{P})$; transformation of $\mathrm{OM}$ in the soil; and $\mathrm{N}_{2}$ fixation by the soil microbial biomass (Joniec 2018). Multiple species of consecutively occurring microbes present in the soil decompose OM through the processes of biodegradation and biotransformation using a broad range of enzymes, the complexity of which depends on the variety of organic substrates available for degradation (Joniec 2018).

In order to prevent negative and irreversible changes occurring in the soil environment, the application of waste materials to the soil must be preceded by the widest testing spectrum that is possible. Różyło et al. (2015), Stefaniuk et al. (2015), and Różyło et al. (2017) conducted chemical and toxicological tests and demonstrated that the application of $\mathrm{BD}$ and carboniferous rock to soil disturbs the ionic balance of soil, and they also showed that there was a negative effect of the application of waste materials on certain organisms (e.g., reduction in luminescence of Vibrio fischeri following the application of carboniferous rock (Różyło et al. 2015). This suggests that the properties of BD and carboniferous rock added to the soil separately or in combination have a significant effect on the growth of microorganisms and on the enzymatic activity of soil microorganisms. Moreover, transfer of a portion of OM, which is undergoing the process of decomposition under natural conditions (aerobic and anaerobic), to the controlled conditions (anaerobic) in the case of BD and from anaerobic to aerobic conditions in the case of MS extracted from a considerable depth, may have of significance effect for microbial processes in the soil following the application of the tested materials. The number of microorganisms and, in particular, the enzymatic activity of the soil constitute a precise reflection of the conditions of the soil. Following are the important parameters that reflect soil quality: quantity and quality of $\mathrm{OM}$, soil structure, $\mathrm{pH}$, and physicochemical properties. Microorganisms play a key role in the transformation of soil components of nutritional importance for the plants. Therefore, information regarding the number of microorganisms and enzymatic activity of the soil is very helpful for the formation of optimum edaphic conditions for the plants. In addition, the type of fertilizer applied has a tremendous effect on the number of microorganisms and the community of microorganisms in the soil (Subhani et al. 2001; Joniec 2013; Jian et al. 2016).

In the case of degraded soils, the use of microbial indices aids in the assessment of the ecological state of the soil, its biological activity, fertility, and the level of toxicity present in it. Despite the number of studies published on the agricultural recycling of BD from biogas plant and mineral mining waste, to the best of our knowledge, there is no comprehensive data regarding the microbiological and biochemical assessment of the effect of the application of BD and MS on the soil. Therefore, the aim of this study was not only to propose the method for the management of biogas installation waste and mineral waste from the extraction industry, but primarily to assess the biological quality of podzolic soil after introducing various concentrations of these wastes. The processes of biodegradation and biotransformation of organic matter in the soil were evaluated based on microbial and enzymatic indicators. In addition, the study analyzed correlation coefficients with respect to the number of microorganisms and enzymatic activity against the changing physicochemical parameters of the soil.

The pot experiment was carried out in 2015 at the laboratory of the Department of Agricultural Ecology, University of Life Sciences in Lublin. Determination of the number of microorganisms and enzymatic activity was carried out at the Department of Environmental Microbiology, Faculty of Agrobioengineering University of Life Sciences in Lublin.

\section{Materials and methods}

\section{Characteristics of wastes and pot experiment}

BD was provided by biogas plant from the Lublin region of Poland. The raw materials to mesophilic methanogensis $\left(32-42{ }^{\circ} \mathrm{C}\right)$ process ware: corn silage $(70 \%)$, sugar bagasse 
beet $(15 \%)$, fruit pomace $(5 \%)$, dairy wastes $(5 \%)$, and manure $(5 \%)$.

The source of mineral mining waste (MS) was carbonate mudstones, which due to geological time belongs to carboniferous roof rocks, bottom rocks, or interlayers of exploited coal seams in a coal mine located in the Lublin region of Poland. A detailed parameters of the wastes and soil used for testing is provided in Table 1 and broader description is available in our previous publications (Różyło et al. 2015; Różyło et al. 2017).

Plastic pots $(16 \mathrm{~L})$ were filled with PS, to which BD or MS was added.

BD was added to soil at a level of 1.5 and 3\%, which corresponded to 3.402 and $6.804 \mathrm{t}$ d.w. BD ha ${ }^{-1}$. MS was added at a level of 10 and $20 \%$, corresponding to 232.521 and $465.106 \mathrm{t}$ d.w. MS ha ${ }^{-1}$ (Table 2).
The experiment was conducted for a period of 12 months at $20-22{ }^{\circ} \mathrm{C}$ and was $50 \%$ FWC (field water capacity). Microbial and biochemical analyses were performed at three different time points: $24 \mathrm{~h}$ (term 0 ) and 6 and 12 months after the application of the material to the soil.

\section{Microbial analysis of soil}

Microbial analyses were performed by determining the number of colony-forming units (CFUs) of copiotrophs (CTs) microorganisms with high nutritional requirements on modified nutritional broth and oligotrophs (OTs) - microorganisms with low nutritional requirements on dissolved nutritional broth (Ohta and Hattori 1980). To this end, soil extract $(300 \mathrm{~mL})$ was prepared by the addition of peptone $(10 \mathrm{~g})$, yeast extract $(10 \mathrm{~g}), \mathrm{NaCl}(5 \mathrm{~g})$, agar $(20 \mathrm{~g})$ and demineralized

Table 1 Chemical characteristic of materials used in the experiment (PS podzolic soil, BD biogas digestate, $M S$ mining waste) (Różyło et al. 2015)

\begin{tabular}{|c|c|c|c|}
\hline Parameters and elements & PS & $\mathrm{BD}$ & MS \\
\hline Dry matter (\%) & - & $8-9$ & $75-80$ \\
\hline $\mathrm{pH}$ (in $1 \mathrm{M} \mathrm{KCl}$ ) & $4.4 \pm 0.23$ & $9.9 \pm 0.47$ & $7.8 \pm 0.31$ \\
\hline $\mathrm{EC}(\mathrm{mS} / \mathrm{cm})$ & $1.20 \pm 0.17$ & $3.70 \pm 0.25$ & $0.84 \pm 0.19$ \\
\hline $\mathrm{C} / \mathrm{N}$ & 23.0 & 22.0 & 77.4 \\
\hline $\mathrm{N} / \mathrm{P}$ & 8.3 & 5.2 & 245.3 \\
\hline $\mathrm{MN}(\%$ of TN) & & 62 & 5 \\
\hline \multicolumn{4}{|l|}{$\mathrm{mg} \mathrm{kg}^{-1} \mathrm{DW}$} \\
\hline TOC & $9506 \pm 781$ & $633,027 \pm 1891$ & $281,195 \pm 3180$ \\
\hline $\mathrm{TN}$ & $413.7 \pm 89$ & $28,820 \pm 118$ & $3631 \pm 177$ \\
\hline $\mathrm{P}$ & $49.4 \pm 4.8$ & $5580.6 \pm 29.4$ & $14.8 \pm 27.1$ \\
\hline $\mathrm{K}$ & $45.1 \pm 3.5$ & $26,906.9 \pm 39.8$ & $333.8 \pm 11.9$ \\
\hline $\mathrm{Mg}$ & $10.7 \pm 0.7$ & $4420.4 \pm 30.4$ & $139.8 \pm 5.3$ \\
\hline $\mathrm{Fe}$ & $393.6 \pm 12.9$ & $1445.4 \pm 19.6$ & $4200.8 \pm 24.3$ \\
\hline $\mathrm{Ca}$ & $222.0 \pm 18.5$ & $311.6 \pm 27.3$ & $761.0 \pm 37.1$ \\
\hline $\mathrm{Na}$ & $603.3 \pm 29.4$ & $2900.2 \pm 38.9$ & $1450.3 \pm 40.6$ \\
\hline $\mathrm{S}-\mathrm{SO}_{4}$ & $7.8 \pm 0.8$ & $225.1 \pm 2.3$ & $132.7 \pm 1.5$ \\
\hline B & $0.5 \pm 0.04$ & $23.4 \pm 0.15$ & $10.1 \pm 0.09$ \\
\hline $\mathrm{Mn}$ & $61.4 \pm 4.5$ & $246.1 \pm 6.9$ & $96.6 \pm 5.1$ \\
\hline $\mathrm{Cu}$ & $0.5 \pm 0.04$ & $14.2 \pm 0.12$ & $14.6 \pm 0.16$ \\
\hline $\mathrm{Zn}$ & $2.5 \pm 0.2$ & $145.1 \pm 0.4$ & $24.4 \pm 0.7$ \\
\hline $\mathrm{Al}$ & $4505.1 \pm 52.5$ & $512.7 \pm 45.2$ & $20,870.1 \pm 87.3$ \\
\hline $\mathrm{Cr}$ & 10.45 & $<0.1$ & 19.8 \\
\hline $\mathrm{Pb}$ & 10.26 & $<0.1$ & 13.7 \\
\hline $\mathrm{Ni}$ & 11.55 & $<0.1$ & 4.51 \\
\hline $\mathrm{Hg}$ & $<0.1$ & $<0.1$ & $<0.1$ \\
\hline $\mathrm{Sr}$ & 9.91 & $<0.1$ & 5.81 \\
\hline $\mathrm{Ba}$ & 32.20 & $<0.1$ & 0.63 \\
\hline Co & 2.50 & $<0.1$ & $<0.1$ \\
\hline $\mathrm{Cd}$ & 0.47 & 0.29 & $<0.1$ \\
\hline
\end{tabular}

The values are the mean of three analyses; \pm mean standard deviation $(n=3)$

$E C$ electrical conductivity, $D W$ dry weight, $T O C$ total organic carbon, $T N$ total nitrogen, $M N$ mineral nitrogen, $P, K, M g$ available 
Table 2 The total dose of minerals per unit of area $\left(\mathrm{kg} \mathrm{ha}^{-1}\right)$

\begin{tabular}{|c|c|c|c|c|}
\hline \multirow[t]{2}{*}{ Dose (\%) } & \multicolumn{2}{|l|}{$\mathrm{BD}$} & \multicolumn{2}{|l|}{ MS } \\
\hline & 1.5 & 3 & 10 & 20 \\
\hline Dry meter $\left(\mathrm{kg} \mathrm{ha}^{-1}\right)$ & 3402 & 6804 & 232,521 & 465,106 \\
\hline \multicolumn{5}{|l|}{$\left(\mathrm{kg} \mathrm{ha}^{-1}\right)$} \\
\hline TOC & 2153.6 & 4307.2 & $65,383.7$ & $130,767.5$ \\
\hline $\mathrm{TN}$ & 98.0 & 196.1 & 844.3 & 1688.6 \\
\hline MN & 60.76 & 121.6 & 42.2 & 84.4 \\
\hline $\mathrm{P}$ & 19.0 & 38.0 & 3.44 & 6.88 \\
\hline K & 91.5 & 183.0 & 77.43 & 154.86 \\
\hline $\mathrm{Mg}$ & 15.0 & 30.0 & 32.32 & 64.64 \\
\hline $\mathrm{Fe}$ & 4.9 & 9.8 & 976.77 & 1953.55 \\
\hline $\mathrm{Ca}$ & 1.1 & 2.1 & 176.95 & 353.90 \\
\hline $\mathrm{Na}$ & 9.9 & 19.7 & 337.23 & 674.45 \\
\hline $\mathrm{S}-\mathrm{SO}_{4}$ & 0.9 & 1.7 & 30.86 & 61.71 \\
\hline B & 0.08 & 0.16 & 2.35 & 4.70 \\
\hline $\mathrm{Mn}$ & 0.84 & 1.67 & 22.46 & 44.92 \\
\hline $\mathrm{Cu}$ & 0.05 & 0.10 & 3.40 & 6.79 \\
\hline $\mathrm{Zn}$ & 0.49 & 0.99 & 5.67 & 11.35 \\
\hline $\mathrm{Al}$ & 1.74 & 3.49 & 4852.74 & 9705.47 \\
\hline $\mathrm{Cr}$ & $<0.0005$ & $<0.001$ & 4.61 & 9.22 \\
\hline $\mathrm{Pb}$ & $<0.0005$ & $<0.001$ & 3.19 & 6.37 \\
\hline $\mathrm{Ni}$ & $<0.0005$ & $<0.001$ & 1.05 & 2.10 \\
\hline $\mathrm{Hg}$ & $<0.0005$ & $<0.001$ & 0.03 & 0.06 \\
\hline $\mathrm{Sr}$ & $<0.0005$ & $<0.001$ & 1.35 & 2.70 \\
\hline $\mathrm{Ba}$ & $<0.0005$ & $<0.001$ & 0.15 & 0.29 \\
\hline Co & $<0.0005$ & $<0.001$ & 0.03 & 0.06 \\
\hline $\mathrm{Cd}$ & 0.001 & 0.002 & 0.03 & 0.06 \\
\hline
\end{tabular}

$P, K, M g$ available

water $(700 \mathrm{~mL})$ to it. The established cultures were incubated in a thermostat at $28^{\circ} \mathrm{C}$. The CFUs were counted after 4 days for CTs and after 6 days for OTs. The total number of bacteria (TB) was determined on the medium containing soil extract (Korniłłowicz-Kowalska and Bohacz 2005) and incubated in a thermostat at $28^{\circ} \mathrm{C}$. The total number of mold and yeast (TMY) were determined on the Dichloran Rose Bengal Chloramphenicol (DRBC) agar medium with an additional dose of antibiotics [streptomycin $\left(30 \mathrm{mg} \mathrm{L}^{-1}\right)$ and chloramphenicol $\left.\left(2 \mathrm{mg} \mathrm{L}^{-1}\right)\right]$ and incubated at $26^{\circ} \mathrm{C}$. The CFUs of the cellulolytic fungi (CF) were counted on the medium which was prepared according to the study of Korniłłowicz-Kowalska and Bohacz (2005); the incubation was performed for 6 days at $26{ }^{\circ} \mathrm{C}$. The number of proteolytic microorganisms (PM) was determined on Frazier (Rodina 1968) medium as the sole source of $\mathrm{C}, \mathrm{N}$, and energy. The cultures were conducted in a thermostat at $28{ }^{\circ} \mathrm{C}$ for 5 days. All media were sterilized in an autoclave at $1 \mathrm{~atm} ., 121^{\circ} \mathrm{C}$ for $20 \mathrm{~min}$.

The microbial groups were quantitatively estimated using plate dilution method (the pour plate technique), and the numbers were expressed in CFUs $\mathrm{kg}^{-1}$ d.w. of soil, which agrees with the literature (Lee 2015).

\section{Biochemical activity of soil}

The activity of soil enzymes was determined using RayLeigh UV/VIS-1800 spectrophotometer.

The activity of dehydrogenases was determined according to the method described by Casida et al. (1964). Briefly, 3\% solution of 2,3,5-triphenyl tetrazolium chloride was added (substrate) to the soil (6 g), and the obtained suspension was incubated at $37^{\circ} \mathrm{C}$ for $24 \mathrm{~h}$. The resulting triphenyl formazan (TPF) was determined at $485 \mathrm{~nm}$, and the results were presented as mg TPF kg $\mathrm{kg}^{-1}$ d.w. of soil $\mathrm{d}^{-1}$.

The activity of acid and alkaline phosphatases was determined according to the method described by Tabatabai and Bremner (1969). Briefly, to 1-g soil sample, toluene, a universal buffer with $\mathrm{pH}=6.5$ and $\mathrm{pH}=11.0$, was added, respectively, for acid and alkaline phosphatase. Then, $p$-nitrophenyl phosphate (PNP) disodium solution $(0.020 \mathrm{M})$ 
was added as the substrate, and the suspensions were incubated at $37^{\circ} \mathrm{C}$ for $1 \mathrm{~h}$. The released $p$-nitrophenol (PNP) was measured spectrophotometrically at $410 \mathrm{~nm}$, and the results are shown as mg PNP kg${ }^{-1}$ d.w. of soil $\mathrm{h}^{-1}$.

Determination of protease activity was performed according to the method described by Ladd and Butler (1972). Briefly, to a 2-g soil sample, $1 \%$ casein in $0.2 \mathrm{M}$ Tris- $\mathrm{HCl}$ ( $\mathrm{pH}=8.1$ ) buffer was added as the substrate. The suspension was incubated at $50{ }^{\circ} \mathrm{C}$ for $1 \mathrm{~h}$. The protease activity was expressed in mg tyrosine $\mathrm{kg}^{-1}$ d.w. of soil $\mathrm{h}^{-1}$.

Urease activity was determined on the basis of $\mathrm{NH}_{4}^{+}$ ions released during incubation of $10 \mathrm{~g}$ soil with the $0.25 \%$ urea solution as the substrate. The suspension was incubated for $18 \mathrm{~h}$ at $37^{\circ} \mathrm{C}$ (Zantua and Bremner 1975). The enzyme activity was expressed as $\mathrm{mg} \mathrm{N}-\mathrm{NH}_{4}{ }^{+} \mathrm{kg}^{-1}$ d.w. of soil $\mathrm{h}^{-1}$.

All the complementary soil enzymatic activities were consolidated to get the enzymatic activity index (EAI). The EAI is useful in evaluating the general biochemical activity of various soils modified with respect to control. The EAI was calculated as follows:

$\mathrm{EAI}=\Sigma \mathrm{RA}(n) / n$

where RA-the sum of relative activities $(\mathrm{RA}=\mathrm{Ax} / \mathrm{Ac})$; Ax-activity of modified soil for the method; Ac-activity of control soil determined for the method.

\section{Statistical analysis}

The results are shown as means of three replicates ( 3 pots $\times 3$ samples of physicochemical and microbiological analysis $=9$ replicates). Determination of the number of microorganisms and soil enzymatic activity was performed in three replicates ( 3 pots $\times 3$ samples in analysis $=9$ replicates). One-way analysis of variance (ANOVA) and Tukey's post hoc test were used to compare groups within different elicitors. In this study, $\alpha$ values $<0.05$ were regarded as significant. Tukey's honestly significant difference (intermediate between least significant difference test and Scheffe's test) is an easy method to determine the critical significance of differences and is adequate in the case of simple factor systems (equal sample size per group). The correlation of enzymatic activity with changes in soil parameters after the application of waste materials was determined by performing correlation analysis with Statistica 5.0. Significance was set at $P<0.05$.

\section{Results and discussion}

\section{Microbial parameters}

After $24 \mathrm{~h}$ of application of the study materials to soil (term 0 ), the total number of bacteria, proteolytic microorganisms, OTs, and CTs increased when compared with the control soil. However, the total number of fungi and cellulolytic fungi decreased. Carboniferous rock (20\% MS) added to PS had the greatest stimulating effect on the development of OTs and CTs. Soil with 3\% BD was least favorable for both OTs and CTs, as well as for the fungi, yet at the same time, it was most favorable for the development of bacteria (Fig. 1).

Independent of the type of waste applied, after 6 and 12 months of the experiment, counts of the majority of the microorganisms was reduced relative to term 0 . The total number of fungi and cellulolytic fungi were found to be greater in number after 6 and 12 months than that of term 0 . Soil with the addition of $3 \%$ BD had a significantly higher number of fungi than that of soil with the addition of $1.5 \%$ BD, MS (both doses), and control soil. However, after 6 months, control soil showed greater number of cellulolytic fungi than that of other samples. Introduction of $1.5 \% \mathrm{BD}$ to the soil favored the development of cellulolytic fungi than that of control soil. After 6 months, the total bacterial count was the highest in soil with the addition of 3\% BD and 20\% MS. Soil with 3\% BD did not favor the development of proteolytic microorganisms even after 6 months of incubation; the microorganisms were significantly less compared to the other experimental variants. The addition of $1.5 \% \mathrm{BD}$ and $20 \%$ MS favored the growth of proteolytic microorganisms. After 6 months, the number of the remaining microorganisms was comparable to that of the control soil (Fig. 1).

After 12 months, the soil with the addition of 3\% BD contained a higher number of bacteria, fungi, OTs, and proteolytic microorganisms than that of control soil, soil with MS (both doses), and soil with 1.5\% BD. After 12 months, CTs (microorganisms with high nutritional requirements), similar to OTs and PM, reacted positively to all soil modifications with waste, which translated to their greater number than that of control soil. Irrespective of the concentration applied, the introduction of BD and MS to the soil had a negative impact on the number of cellulolytic fungi compared with the control soil. After 12 months, the greatest decrease in the number of cellulolytic fungi was in soil with 10\% MS (Fig. 1).

\section{Enzymatic activity of soil}

During the assessment of soil quality, the number of microorganisms belonging to major groups is not the only important parameter, but the activity of enzymes produced by these microorganisms is equally important. Based on our results (Fig. 2), the dehydrogenase and urease activity increased $24 \mathrm{~h}$ after the application of BD and MS. Particularly high dehydrogenase activity was in the soil with the application of 1.5 and 3\% BD. Increase in the activity of urease was not as notable as in the case of dehydrogenase. The highest urease activity was noted in soil with $3 \%$ 

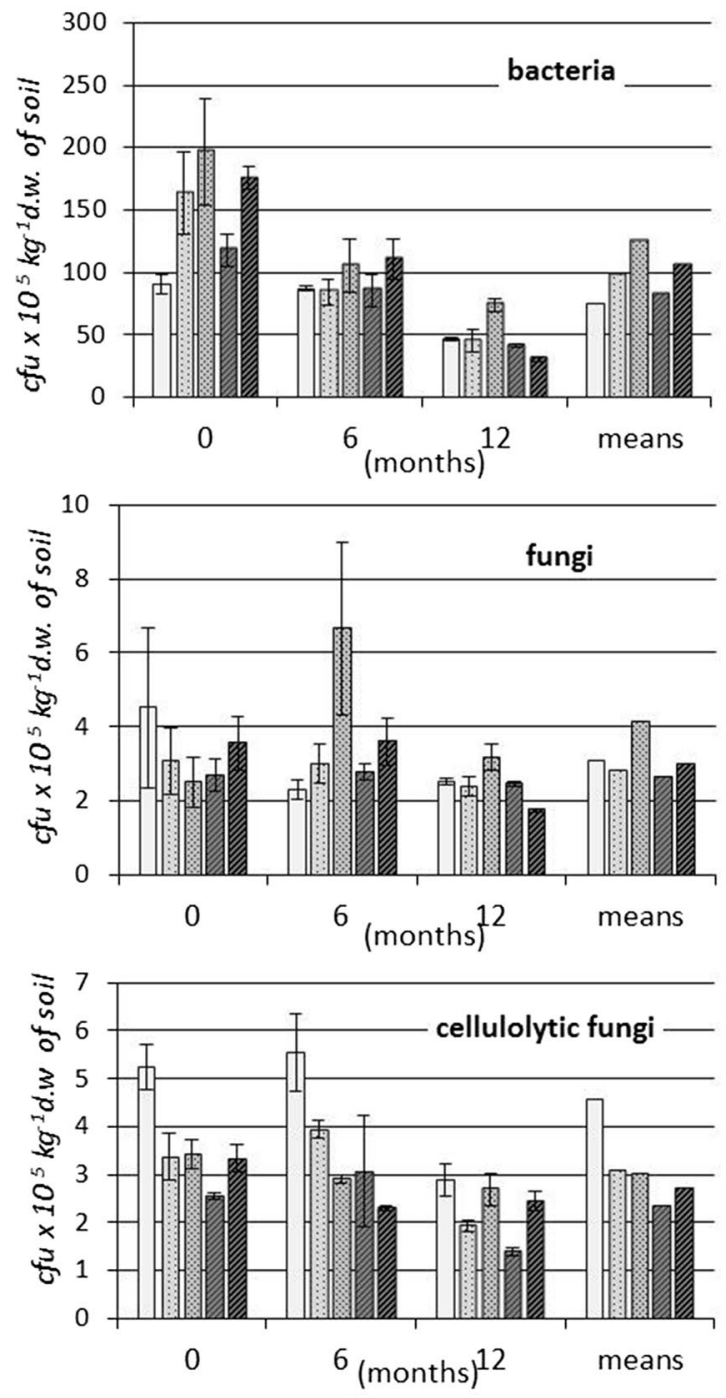

0 1.5\% BD 圆3\% BD 圆 10\% MS 勿 $20 \%$ MS
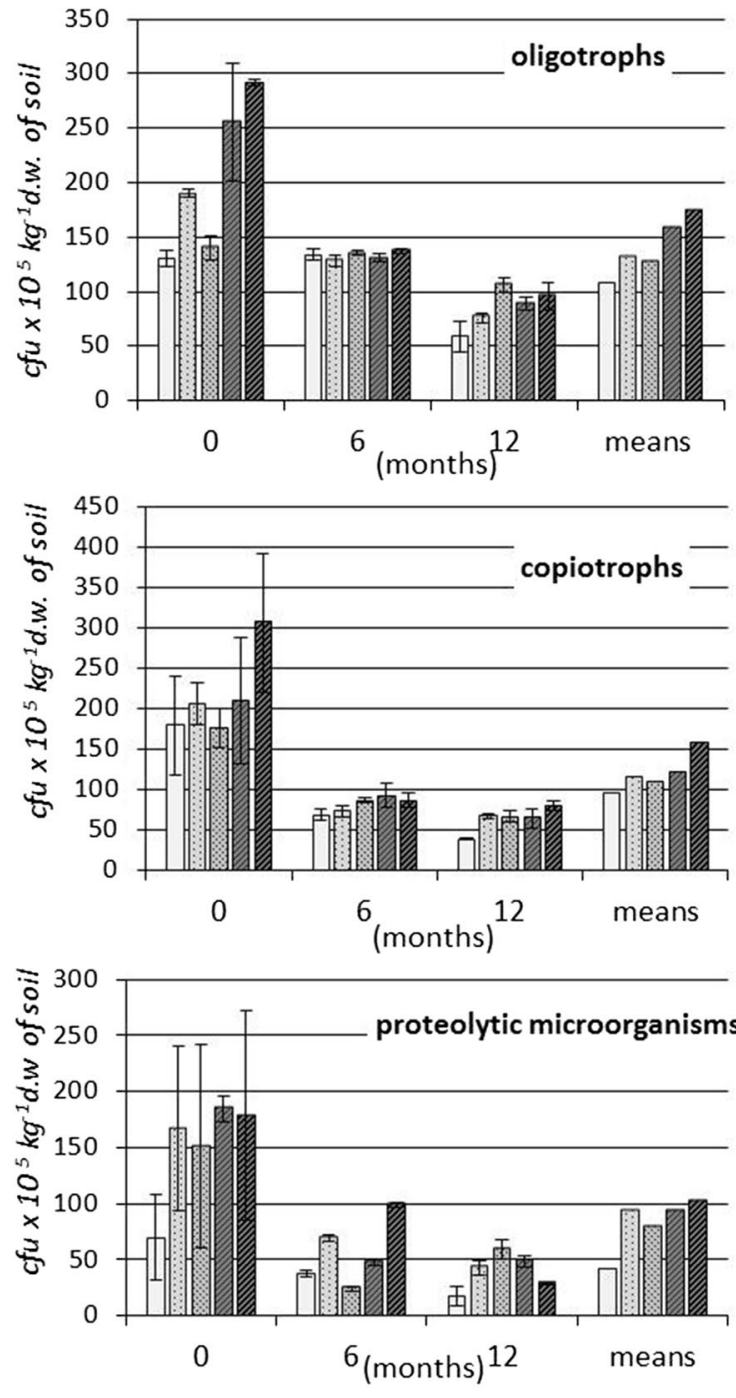

$\square 0 \square 1.5 \%$ BD . $3 \%$ BD $10 \%$ MS $20 \%$ MS

Fig. 1 Changes in the number of selected groups of microorganisms in podzolic soil after the introduction of various waste doses

BD. Acid phosphatase activity increased in soil with $3 \%$ BD, $10 \%$ MS, and 20\% MS, and it decreased in soil with $1.5 \%$ BD compared with control soil. Both 1.5 and 3\% BD significantly increased the protease activity compared with control soil and soil with MS. However, alkaline phosphatase showed the contradictory effect with that of acid phosphatase. In the case of 20 and 30\% MS, the activity of alkaline phosphatase increased, but it decreased in soil with BD (both doses) compared with control soil (Fig. 2).

Irrespective of the experimental variants, the activity of enzymes was lower after 12 months of incubation than that of after $24 \mathrm{~h}$ and 6 months of incubation. The activity of acid phosphatase increased in all experimental variants after 6 months of incubation (with the exception of soil with $3 \% \mathrm{BD}$ ) compared with term 0 . However, it was lower than that of the control soil. The activity of acid phosphatase was stimulated by $20 \%$ MS in comparison with control soil. Protease activity, which reflects N transformations, did not change much even after incubation for 12 months and after the application of different levels of both wastes, but the activity was the lowest after 6 months of incubation. This was probably linked to two factors: changes in soil $\mathrm{pH}$ and the presence of phosphate compounds after the application of wastes (Fig. 2). This is confirmed by the high activity of alkaline phosphatase in the soil after the addition of BD (proportionally to the concentration of $\mathrm{BD}$, which had strongly basic $\mathrm{pH}=9.9$ in $1 \mathrm{M} \mathrm{KCl}$ ), and significantly higher content of available phosphorus in comparison with MS (Tables 1 and 2). The initial recorded high activity of alkaline phosphatase 

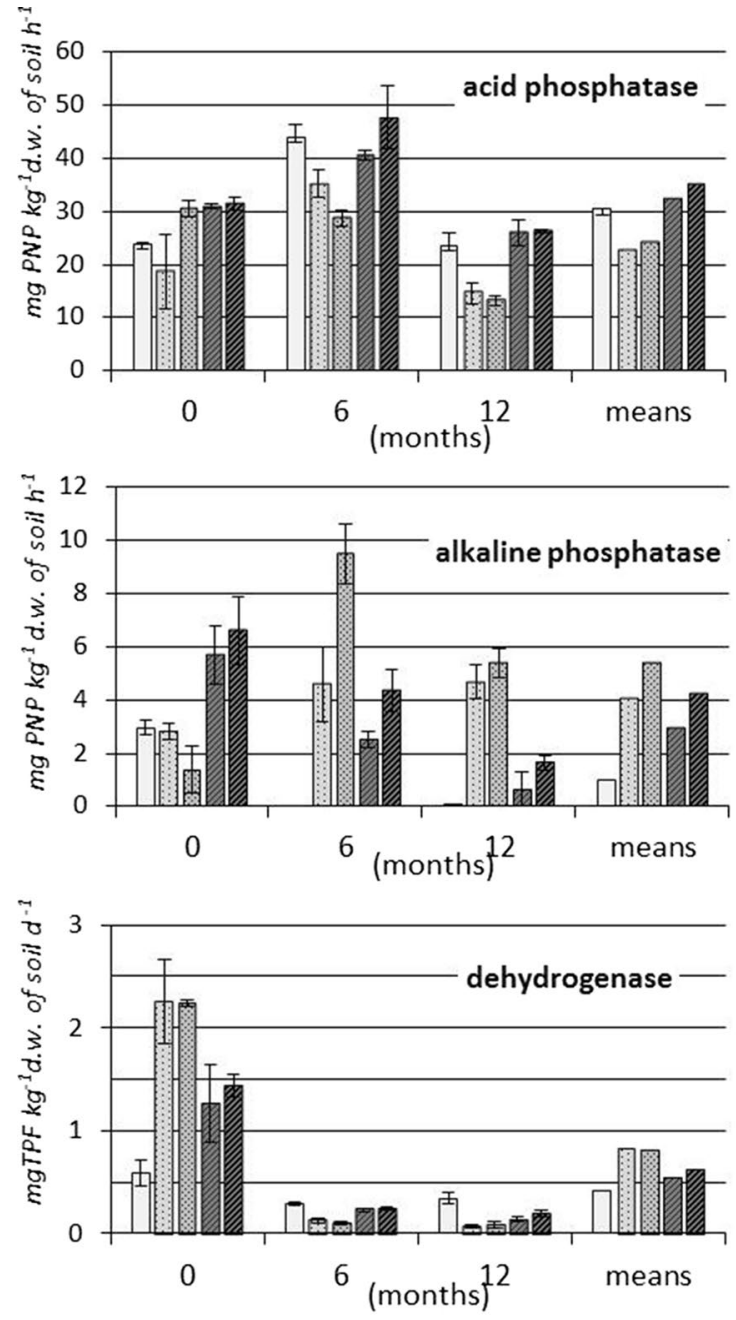

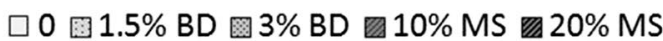
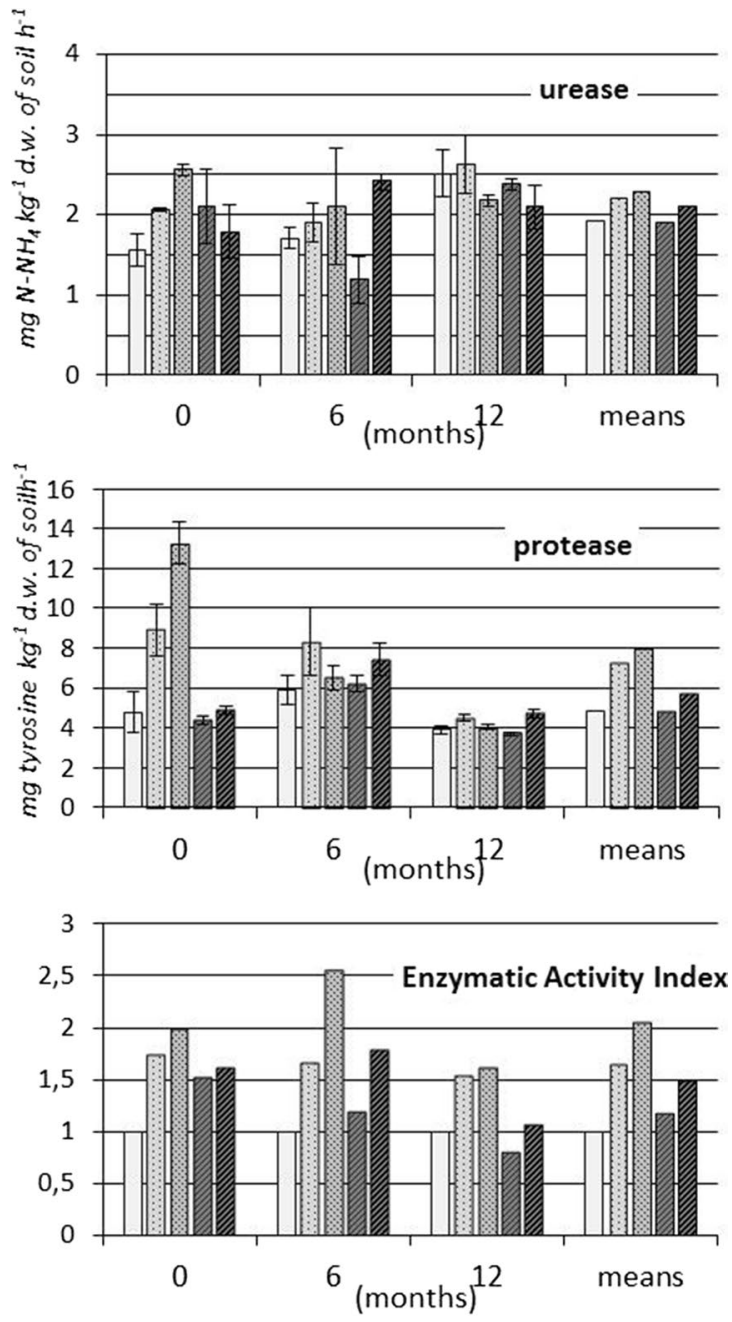

$\square 0$ 圆 1.5\% BD 圆3\% BD 圆 10\% MS 20\% MS

Fig. 2 Dynamics of changes in soil enzyme activity under the influence of introduced waste

in soil containing MS and its successive decrease after 6 and 12 months is probably associated with the decrease in $\mathrm{pH}$ due to the rapid weathering of MS. In this context, it is noteworthy that in the control soil, there is the lack of alkaline phosphatase activity even after 6 and 12 months of incubation, and its activity was high in soil containing BD.

\section{Enzymatic activity index}

The highest enzymatic activity index (EAI) was recorded for soil containing 3\% BD after 6 months of incubation and was recorded for BD (1.5 and 3\%) after $24 \mathrm{~h}$ after 12 months of incubation. In addition, MS increased the value of EAI relative to the control soil. However, soil containing $10 \%$ MS, after 12 months of incubation, was an exception, as it decreased the value of EAI relative to control soil. Mean values from all experimental timepoints have proven that despite the disturbances in the concentration of ionic in the soil after the application of BD and MS, the tested waste materials increased the general soil enzymatic activity (Fig. 2).

\section{Correlations}

Correlation coefficients presented in Table 3 demonstrate that the activity of acid phosphatase did not depend significantly on the number of any of the individual groups of microorganisms. However, we obtained significant positive correlations between alkaline phosphatase activity and the number of fungi in the soil containing BD and MS. The dehydrogenase activity correlated positively and significantly with the number of the oligotrophs, copitrophs, proteolytic microorganisms, and fungi (mold and yeast). Urease 
Table 3 Correlations between the counts of microorganisms and enzyme activity

\begin{tabular}{lcccrc}
\hline Microorganisms & Enzyme activities \\
\cline { 2 - 6 } & Acid phosphatase & $\begin{array}{l}\text { Alkaline } \\
\text { phos- } \\
\text { phatase }\end{array}$ & Dehydrogenase & Urease & Protease \\
& 0.21 & 0.39 & $0.53^{*}$ & -0.29 & 0.11 \\
Oligotrophs (OTs) & 0.02 & 0.25 & $0.68^{*}$ & -0.19 & 0.20 \\
Copiotrophs (CTs) & 0.01 & $0.53^{*}$ & 0.06 & 0.04 & 0.08 \\
Fungi (TMY) & 0.21 & 0.22 & $0.73^{*}$ & -0.09 & $0.61^{*}$ \\
Bacteria (TB) & 0.00 & 0.12 & $0.67^{*}$ & -0.02 & 0.23 \\
Proteolytic microorganisms (PM) & 0.26 & -0.15 & 0.25 & $-0.46^{*}$ & 0.24 \\
Cellulolytic fungi (CF) & 1.00 & -0.05 & -0.19 & -0.23 & 0.29 \\
Acid phosphatase & -0.05 & 1.00 & -0.03 & 0.02 & -0.06 \\
Alkaline phosphatase & -0.19 & -0.03 & 1.00 & 0.00 & $0.45^{*}$ \\
Dehydrogenase & -0.23 & 0.02 & 0.00 & 1.00 & 0.10 \\
Urease & 0.29 & -0.06 & $0.45^{*}$ & 0.10 & 1.00 \\
Protease & & & & &
\end{tabular}

*Significant at the 0.05 probability level activity showed a negative correlation with the number of cellulolytic fungi, which suggests their antagonistic nature relative to organisms producing urease. The protease activity and bacterial number demonstrated a relatively high level of positive correlation.

Calculation of statistical relationships between changes in the soil parameters and the number of microorganisms has demonstrated that the number of OTs, CTs, and proteolytic microorganisms was significantly and positively correlated with $\mathrm{pH}, \mathrm{TOC}, \mathrm{TN}$, and micronutrient contents. Phosphorus was the exception, as its content was strongly and negatively associated with the counts of OTs, CTs, and proteolytic microorganisms. However, mineral nitrogen (MN) and potassium did not show any significant correlations with the number of microorganisms (Table 4). The number of fungi and bacteria correlated significantly and positively with the content of $\mathrm{MN}, \mathrm{P}$, and $\mathrm{K}$. The number of cellulolytic fungi were negatively correlated with the $\mathrm{pH}$ of the soil and positively correlated with $\mathrm{P}$ content in the soil.

The activity of acid phosphatase was significantly and positively correlated with the content of TOC, TN, and micronutrients, whereas it was negatively with $\mathrm{P}$ content (significantly), $\mathrm{MN}$, and $\mathrm{K}$ content (insignificantly) (Table 5). The activity of other soil enzymes showed a significant positive correlation with the content of MN, P and K. The other soil parameters did not have statistically significant correlations with the activity of alkaline phosphatase, dehydrogenase, urease, and protease. However, it is noteworthy that in the majority of cases, these correlations were negative (Table 5).

Biodegradation of organic carbon, nitrogen, and phosphorus by the microorganisms requires the expenditure of high energy, and thus the secretion of active enzymes (carbon and phosphorus) typically increases under the conditions of elevated availability of nitrogen. This is confirmed by Marklein and Houlton (2011), who demonstrated that phosphatase activity typically increases under the conditions of high nitrogen availability, suggesting the accelerated phosphorus cycle.

Fatemi et al. (2016) obtained contradicting results in which an increase in the activity of acid phosphatase and $\beta$-glucosidase in acidic soil was more dependent on the availability of phosphorus than that of nitrogen. However, enriching soil with nitrogen decreased the activity of enzymes. This result is in-line with a previous study (Ramirez et al. 2012). However, the majority of studies report that following the resource allocation theory, the addition of nitrogen stimulates the activity of enzymes participating in the mineralization cycles of carbon, nitrogen, and phosphorus (Joniec 2013; Johnson et al. 2010).

A meta-analysis based on 65 published studies revealed that nitrogen fertilization significantly increased the activities of $\beta$-D-cellobiosidase; acid phosphatase; $\beta$-1,4-xylosidase; $\beta$-1,4-glucosidase; $\alpha$-1,4-glucosidase; and urease. There was an average increase in the activities of $\alpha-1,4$-glucosidase, $\beta$-1,4-glucosidase, $\beta$-1,4-xylosidase, and $\beta$-D-cellobiosidase (the carbon-acquiring enzymes), but decreased the activities of peroxidase, phenol oxidase, and soil oxidative enzymes (Jian et al. 2016). Shi et al. (2018) additionally demonstrated that the form of nitrogen is also significant in increasing soil activity (organic or inorganic). In most cases, the addition of mixed nitrogen (inorganic/organic) increased the enzyme activities compared with that of single addition of inorganic nitrogen, thus proving that the inorganic and organic forms of nitrogen affect the enzyme activities. This is confirmed in our study, in which BD containing large amounts of MN increased the enzymatic activity of the soil to a greater extent than that of MS (Fig. 2-EAI). BD demonstrated a positive effect on most the tested enzyme activities especially that of protease and urease during the entire study period and 
Table 4 Correlations of microorganism counts with the changes of soil parameters after application of waste materials

\begin{tabular}{|c|c|c|c|c|c|c|}
\hline Parameters & Oligotrophs (OTs) & Copiotrophs (CTs) & Fungi (TMY) & Bacteria (TB) & $\begin{array}{l}\text { Proteolytic microor- } \\
\text { ganisms (PM) }\end{array}$ & $\begin{array}{l}\text { Cellulolytic } \\
\text { fungi (CF) }\end{array}$ \\
\hline $\mathrm{pH}$ & $0.81^{*}$ & $0.74 *$ & -0.27 & 0.00 & $0.89 *$ & $-0.74^{*}$ \\
\hline TOC & $0.94 *$ & $0.90 *$ & -0.45 & -0.15 & $0.94 *$ & -0.63 \\
\hline $\mathrm{TN}$ & $0.92 *$ & $0.90 *$ & -0.40 & -0.09 & $0.93^{*}$ & -0.61 \\
\hline $\mathrm{MN}$ & -0.49 & -0.15 & $0.91 *$ & $0.95^{*}$ & -0.39 & 0.50 \\
\hline $\mathrm{P}$ & $-0.90 *$ & -0.64 & $0.90 *$ & $0.78^{*}$ & $-0.83^{*}$ & $0.72 *$ \\
\hline K & -0.25 & 0.08 & $0.84^{*}$ & $0.92 *$ & -0.14 & 0.34 \\
\hline $\mathrm{Mg}$ & $0.75^{*}$ & $0.83 *$ & -0.09 & 0.24 & $0.81^{*}$ & -0.44 \\
\hline $\mathrm{Fe}$ & $0.94 *$ & $0.91 *$ & -0.46 & -0.16 & $0.93^{*}$ & -0.64 \\
\hline $\mathrm{Ca}$ & $0.93^{*}$ & $0.85^{*}$ & -0.46 & -0.16 & $0.91 *$ & -0.64 \\
\hline $\mathrm{Na}$ & $0.91 *$ & $0.90 *$ & -0.45 & -0.15 & $0.91 *$ & -0.63 \\
\hline $\mathrm{S}-\mathrm{SO}_{4}$ & $0.92 *$ & $0.91 *$ & -0.45 & -0.15 & $0.90^{*}$ & -0.63 \\
\hline $\mathrm{B}$ & $0.91 *$ & $0.83 *$ & -0.45 & -0.15 & $0.93^{*}$ & -0.63 \\
\hline $\mathrm{Mn}$ & $0.89^{*}$ & $0.89 *$ & -0.45 & -0.14 & $0.92 *$ & -0.63 \\
\hline $\mathrm{Cu}$ & $0.94^{*}$ & $0.90 *$ & -0.46 & -0.16 & $0.93^{*}$ & -0.64 \\
\hline $\mathrm{Zn}$ & $0.92 *$ & $0.90 *$ & -0.42 & -0.11 & $0.90^{*}$ & -0.62 \\
\hline $\mathrm{Al}$ & $0.93^{*}$ & $0.91 *$ & -0.47 & -0.16 & $0.93^{*}$ & -0.64 \\
\hline $\mathrm{Cr}$ & $0.88^{*}$ & $0.83 *$ & -0.47 & -0.17 & $0.93^{*}$ & -0.64 \\
\hline $\mathrm{Pb}$ & $0.83^{*}$ & $0.88 *$ & -0.47 & -0.17 & $0.93^{*}$ & -0.64 \\
\hline $\mathrm{Ni}$ & $0.91^{*}$ & $0.89 *$ & -0.47 & -0.16 & $0.90^{*}$ & -0.64 \\
\hline $\mathrm{Hg}$ & $0.93 *$ & $0.84^{*}$ & -0.46 & -0.16 & $0.91 *$ & -0.64 \\
\hline $\mathrm{Sr}$ & $0.90^{*}$ & $0.87^{*}$ & -0.47 & -0.16 & $0.90^{*}$ & -0.64 \\
\hline $\mathrm{Ba}$ & $0.92 *$ & $0.85^{*}$ & -0.47 & -0.17 & $0.92 *$ & -0.65 \\
\hline Co & $0.93^{*}$ & $0.89 *$ & -0.46 & -0.16 & $0.93^{*}$ & -0.64 \\
\hline $\mathrm{Cd}$ & $0.95^{*}$ & $0.90^{*}$ & -0.45 & -0.15 & $0.90^{*}$ & -0.63 \\
\hline
\end{tabular}

*Significant at the 0.05 probability level

showed a positive effect on dehydrogenase and alkaline phosphatase activities after $24 \mathrm{f}$ and after 6 and 12 months, respectively. García-Sánchez et al. (2015) observed a similar tendency in enzymatic activity after introducing the digestate to the soils. Moreover, it has been shown that the number of OTs, CTs, and PM had a significant positive correlation with the content of $\mathrm{TN}$, whereas the counts of fungi and bacteria had a significant positive correlation with the content of MN (Table 4). The nitrogen in the BD and MS was of greater importance to improve the soil parameters and the activity of soil enzymes. The activity of acid phosphatase had a significant positive correlation with $\mathrm{TN}$ and negative correlation with MN (Table 5). The activity of the other tested soil enzymes had a significant positive correlation with the content of MN.

The number of microorganisms and the enzymatic activity of the soil were largely dependent on the amount and the bioavailability of phosphorus, potassium, and magnesium (Joniec 2013). However, in our study, the phosphorus content showed a negative correlation with the number of OTs, CTs, and proteolytic microorganisms (PM). This probably stems from the lower immunity of these organisms to a higher concentration of phosphorus in the soil than that of other bacteria (TB), fungi (TMY) and cellulolytic fungi (CF), the counts of which positively correlated with the content of phosphorus and potassium in the soil. Magnesium content in the soil showed a positive correlation with the number of OTs, CTs, and PM (Table 4). Table 5 demonstrates that changes in the content phosphorus and potassium were significant for the activity of soil enzymes. Negative correlations were found only for acid phosphatase (significantly with phosphorus and insignificantly with potassium), and for the other enzymes, these correlations were positive.

Other soil parameters are also significant for the activity of microorganisms. For example, low TOC and humic acid content and low values cation exchange capacity (CEC) in soil shows the low activity of dehydrogenase and acid phosphatase (Jośko et al. 2014). However, in soils containing a rich absorption complex and higher content of $\mathrm{OM}$, there is an increased activity of dehydrogenase and acid phosphatase. This confirms the possibility to immobilize toxins and reduce their bioavailability after increasing TOC or loamy minerals content. The stimulating effect of carbon, nutrients, and elevated absorption capacity of soil on the activity of enzymes after the application of biochar has also been confirmed. This stems from the improvement of 
Table 5 Correlations of enzyme activity with the changes of soil parameters after application of waste materials

\begin{tabular}{|c|c|c|c|c|c|}
\hline Parameters & Acid phosphatase & $\begin{array}{l}\text { Alkaline phos- } \\
\text { phase }\end{array}$ & Dehydrogenase & Urease & Protease \\
\hline $\mathrm{pH}$ & 0.65 & 0.09 & -0.43 & -0.16 & -0.31 \\
\hline TOC & $0.82 *$ & -0.08 & -0.55 & -0.26 & -0.46 \\
\hline $\mathrm{TN}$ & $0.79 *$ & -0.03 & -0.51 & -0.21 & -0.41 \\
\hline $\mathrm{MN}$ & -0.65 & 0.94* & $0.92 *$ & $0.95^{*}$ & $0.93 *$ \\
\hline $\mathrm{P}$ & $-0.92^{*}$ & $0.73^{*}$ & $0.95^{*}$ & $0.85^{*}$ & $0.94 *$ \\
\hline K & -0.45 & $0.92 *$ & $0.79 *$ & $0.91 *$ & $0.85^{*}$ \\
\hline $\mathrm{Mg}$ & 0.57 & 0.30 & -0.20 & 0.12 & -0.09 \\
\hline $\mathrm{Fe}$ & $0.83^{*}$ & -0.10 & -0.57 & -0.28 & -0.48 \\
\hline $\mathrm{Ca}$ & $0.83^{*}$ & -0.10 & -0.57 & -0.28 & -0.48 \\
\hline $\mathrm{Na}$ & $0.81 *$ & -0.08 & -0.55 & -0.27 & -0.46 \\
\hline $\mathrm{S}-\mathrm{SO}_{4}$ & $0.83 *$ & -0.08 & -0.55 & -0.27 & -0.46 \\
\hline B & $0.79 *$ & -0.08 & -0.55 & -0.26 & -0.46 \\
\hline $\mathrm{Mn}$ & $0.82 *$ & -0.08 & -0.55 & -0.26 & -0.46 \\
\hline $\mathrm{Cu}$ & $0.83^{*}$ & -0.09 & -0.56 & -0.27 & -0.47 \\
\hline $\mathrm{Zn}$ & $0.81 *$ & -0.05 & -0.52 & -0.23 & -0.43 \\
\hline $\mathrm{Al}$ & $0.83 *$ & -0.10 & -0.57 & -0.28 & -0.48 \\
\hline $\mathrm{Cr}$ & $0.83^{*}$ & -0.10 & -0.57 & -0.28 & -0.48 \\
\hline $\mathrm{Pb}$ & $0.81 *$ & -0.10 & -0.57 & -0.28 & -0.48 \\
\hline $\mathrm{Ni}$ & $0.83^{*}$ & -0.10 & -0.57 & -0.28 & -0.48 \\
\hline $\mathrm{Hg}$ & $0.83 *$ & -0.09 & -0.56 & -0.27 & -0.47 \\
\hline $\mathrm{Sr}$ & $0.83 *$ & -0.10 & -0.57 & -0.28 & -0.48 \\
\hline $\mathrm{Ba}$ & $0.80^{*}$ & -0.11 & -0.58 & -0.29 & -0.49 \\
\hline Co & $0.83^{*}$ & -0.09 & -0.56 & -0.27 & -0.47 \\
\hline $\mathrm{Cd}$ & $0.82 *$ & -0.08 & -0.55 & -0.26 & -0.46 \\
\hline
\end{tabular}

TOC total organic carbon, $T N$ total nitrogen, $M N$ mineral nitrogen

*Significant at the 0.05 probability level physicochemical properties of the soil (e.g., pH, carbon content, and CEC) and partially from the increased retention of water in the soil (Oleszczuk et al. 2014). In this study, the number of OTs, CTs, and proteolytic microorganisms were positively correlated with $\mathrm{pH}$ and TOC. Negative correlations could only be indicated between the number of cellulolytic fungi and pH (significant) and TOC (insignificant) (Table 4). In the case of activity of soil enzymes, significant correlations were obtained solely between the activity of acid phosphatase and TOC (Table 5).

Studies regarding the effect of micronutrients, including heavy metals, on the growth of soil microorganisms, show conflicting results, and it is difficult to establish their toxicity limits for soil microorganisms (Bååth 1989). Issues in defining the toxicity of heavy metals include the determination of their bioavailability in soil or total concentration of metals in soil (Naidu et al. 2006), which may lead to various conflicting results on the influence of metals on the activity of soil microorganisms.

In general, heavy metals have a negative effect on the growth of microorganisms, may damage the cell membrane, alter enzyme specificity, disturb cellular functions, and damage DNA structure (Rathnayake et al. 2010). Certain soil microbes tolerate the presence of heavy metals; therefore, they are used in the bioremediation of contaminated soils (Abdu et al. 2017). Kandeler et al. (1996) discovered that enzymes associated with nitrogen, phosphorus, and sulfur cycles are most sensitive to heavy metals. Smejkalova et al. (2003) demonstrate that CFUs of all bacteria and micromycetes were reduced with the increase in the concentration of heavy metals, but the decrease in CFUs was more significant in the case of OTs and spore-forming bacteria. In this study, the application of waste materials was associated with the introduction of micronutrients, including certain amounts of heavy metals (especially after the application of MS). However, in this study, we obtained significant positive correlations between the number of OTs, CTs, and PM with the content of micronutrients, including heavy metals (Table 4). Perhaps the concentration of heavy metals did not exceed the limit of toxicity and the stimulation of these organisms resulted from the general increase in the amount or availability of micronutrients.

According to Jośko et al. (2014), significant level of toxicity of heavy metals, including their nanomolecular forms was observed for soil enzymes but only at high concentrations. Some heavy metals are included among micronutrients, the minor amounts of which are indispensable for the 
proper functioning of organisms and their minor amounts stimulate the enzymatic activity of soil as well. Jośko et al. (2014) observed a considerable level of stimulation of urease activity with the use of nano-Ni and nano- $\mathrm{Cr}_{2} \mathrm{O}_{3}$ in the soil. This may be related to the release of $\mathrm{Ni}$ ions, which are a part of the active site of the enzyme (Polacco et al. 2013).

In this study, we did not find any directional relationships between the activity of urease and the application of MS, in which small amounts of Ni were introduced (Table 2, Fig. 2). Moreover, we did not find significant correlations between enzyme activity and the applied micronutrients with waste. However, acid phosphatase activity showed a positive significant correlation with the increase in the concentration of heavy metals and the content of other micronutrients (Table 5). The number of microorganisms had a stronger relationship with the content of micronutrients, as the number of OTs, CTs, and proteolytic microorganisms correlated positively with their content (Table 4). The number of fungi, bacteria, and cellulolytic fungi exhibited negative and insignificant correlations with the content of micronutrients, including heavy metals. According to Gao et al. (2010), a considerable amount of soil contamination with $\mathrm{Cd}, \mathrm{Zn}, \mathrm{Cu}, \mathrm{Pb}, \mathrm{Cr}$, and $\mathrm{Ni}$ reduced the bacterial population and inhibited the activity of phosphatase, urease, and dehydrogenase. However, the addition of waste silt with low content of heavy metals increased the activity of dehydrogenase, phosphatase, and beta-glucosidase. This has been attributed to the elevated activity of microorganisms in the soil which is stimulated by the addition of heavy metals below their toxic level (Chander and Brookes 1991).

The dehydrogenase activity, as an intercellular enzyme, is more sensitive to the presence of contaminants compared to extracellular enzymes; therefore, it is an important indicator of heavy metals contamination in soil (Jian et al. 2016). The activity of extracellular enzymes (e.g., urease and phosphatases) can also be affected by the physicochemical properties of the soil (Huang et al. 2005), wherein they can be absorbed by the clay or natural OM, due to which NPs may have more difficulty in binding with the enzymes (Jośko et al. 2014).

\section{Conclusion}

The tested materials increased the number of soil microorganisms and increased the activity of the major soil enzymes. This resulted in an increase in the process of decomposition of the biomass compared with control soil. The application of $\mathrm{BD}$ and MS showed a positive effect on the number of soil microorganisms and soil enzymes. The activity of microorganisms is higher in soil with the balanced ionic environment. This gives the possibility for sustainable development of microorganism assemblage and the complex action of soil enzymes. The disturbing factor for the balance of soil microbes can be both deficiency and excess of macronutrients and to a lesser extent on the content of micronutrients as well. Heavy metals constitute a separate issue, for which no negative effect was found with respect to the number of microorganisms and enzymatic activity in the soil reclaimed with waste. This means that disturbance in the ionic balance and heavy metal content after application of waste remains within the tolerance range of the tested microorganisms and enzyme action. The possible benefits of increasing the content of macro- and micronutrients in the soil outweigh the harmful effect of heavy metals and other harmful compounds. The positive effect may include immobilization of toxins and their reduced bioavailability after increasing the organic carbon or loamy mineral content. In summary, mineral mining waste, in particular, biogas digestate, can be used to reclaim acidic nutrient-poor podzolic soil without causing a negative effect on the soil microorganisms. This suggests that the tested wastes can be used in agricultural practice to improve the microbiological activity of the soil with a large reserve of safety for the soil environment, and thus for plants and other elements of the food chain. Therefore, the agronomic use of this waste can be considered a good method of utilization.

Acknowledgements This study was supported by the research potential support grant of the Polish Ministry of Science and Higher Education as part of the statutory activity RKE-DS/4 of the Faculty of Agrobioengineering, University of Life Sciences, Lublin, Poland.

\section{Compliance with ethical standards}

Conflict of interest All authors declare that they have no conflict of interest.

Open Access This article is distributed under the terms of the Creative Commons Attribution 4.0 International License (http://creativeco mmons.org/licenses/by/4.0/), which permits unrestricted use, distribution, and reproduction in any medium, provided you give appropriate credit to the original author(s) and the source, provide a link to the Creative Commons license, and indicate if changes were made.

\section{References}

Abdu N, Abdullahi AA, Abdulkadir A (2017) Heavy metals and soil microbes. Environ Chem Lett 15:65-84. https://doi.org/10.1007/ s10311-016-0587-x

Alburquerque JA, de la Fuente C, Campoy MM, Carrascoa L, Nájerab I, Baixaulib C, Caravacaa F, Roldána A, Cegarraa J, Bernal MP (2012) Agricultural use of digestate for horticultural crop production and improvement of soil properties. Eur J Agron 43:119-128. https://doi.org/10.1016/j.eja.2012.06.001

Bååth E (1989) Effects of heavy metals in soil on microbial processes and populations (a review). Water Air Soil Pollut 47(3-4):335379. https://doi.org/10.1007/BF00279331

Casida LEJ, Klein DA, Santoro T (1964) Soil dehydrogenase activity. Soil Sci 98:371-376 
Chander K, Brookes PC (1991) Effects of heavy metals from past applications of sewage sludge on microbial biomass and organic matter accumulation in a sandy loam and a silty loam UK soil. Soil Biol Biochem 23:927-932. https://doi.org/10.1016/00380717(91)90172-G

Fatemi FR, Fernandez IJ, Simon KS, Dail DB (2016) Nitrogen and phosphorus regulation of soil enzyme activities in acid forest soils. Soil Biol Biochem 98:171-179. https://doi.org/10.1016/j. soilbio.2016.02.017

Gao Y, Zhou P, Mao L, Zhi Y, Shi W-J (2010) Assessment of effects of heavy metals combined pollution on soil enzyme activities and microbial community structure: modified ecological doseresponse model and PCR-RAPD. Environ Earth Sci 60:603612. https://doi.org/10.1007/s12665-009-0200-8

García-Sánchez M, Siles JA, Cajthaml T, García-Romera I, Tlustoš P, Száková J (2015) Effect of digestate and fly ash application on soil functional properties and microbial communities. Eur $\mathbf{J}$ Soil Biol 71:1-12. https://doi.org/10.1016/j.ejsobi.2015.08.004

Huang P-M, Wang M-K, Chiu C-Y (2005) Soil mineral-organic matter-microbe interactions: impacts on biogeochemical processes and biodiversity in soils. Pedobiologia 49:609-635. https://doi. org/10.1016/j.pedobi.2005.06.006

Jabłońska B (2012) Sorption of phenol on rock components occurring in mine drainage water sediments. Int J Miner Process 71:104-105. https://doi.org/10.1016/j.minpro.2011.12.008

Jian S, Li J, Chen J, Wang G, Mayes MA, Dzantor KE, Hui D, Luo Y (2016) Soil extracellular enzyme activities, soil carbon and nitrogen storage under nitrogen fertilization: a meta-analysis. Soil Biol Biochem 101:32-43. https://doi.org/10.1016/j.soilbio.2016.07.003

Johnson D, Moore L, Green S, Leith ID, Sheppard LJ (2010) Direct and indirect effects of ammonia, ammonium and nitrate on phosphatase activity and carbon fluxes from decomposing litter in peatland. Environ Pollut 158:3157-3163. https://doi. org/10.1016/j.envpol.2010.06.038

Joniec J (2013) Microbiological transformation of N, S and P in degraded soil subjected to one-year remediation with various wastes. Pol J Soli Sci 46:61-75

Joniec J (2018) Enzymatic activity as an indicator of regeneration processes in degraded soil reclaimed woth various types of waste. Int J Environ Sci Technol 15:2241-2252. https://doi. org/10.1007/s13762-017-1602-x

Jośko I, Oleszczuk P, Futa B (2014) The effect of inorganic nanoparticles $\left(\mathrm{ZnO}, \mathrm{Cr}_{2} \mathrm{O}_{3}, \mathrm{CuO}\right.$ and $\left.\mathrm{Ni}\right)$ and their bulk counterparts on enzyme activities in different soils. Geoderma 232-234:528537. https://doi.org/10.1016/j.geoderma.2014.06.012

Kandeler E, Kampichler C, Horak O (1996) Influence of heavy metals on functional diversity of soil microbial communities. Biol Fertil Soils 23:299-306. https://doi.org/10.1007/BF00335958

Korniłłowicz-Kowalska T, Bohacz J (2005) The influence of keratinbark and keratin-bark-straw composts and development of bacteria and fungi in two soils under different plant cultivation systems. Zesz Probl Post Nauk Rol 506:245-259 (in polish)

Ladd JN, Butler JAH (1972) Short-term assays of soil proteolytic enzyme activities using proteins and dipeptide derivatives as substrates. Soil Biol Biochem 4:19-30. https://doi.org/10.1016/00380717(72)90038-7

Lee PS (2015) Quantitation of microorganisms. In: Goldman E, Green LH (eds) Practical handbook of microbiology, 3rd ed. CRC Press, Taylor \& Francis Group, pp 19. eBook ISBN: 9781420009330

Lopedota O, Leogrande R, Fiore A, Debiase G, Montemurro F (2013) Yield and soil responses of melon grown with different organic fertilizers. J Plant Nutr 36(3):415-428. https://doi. org/10.1080/01904167.2012.748062

Mader BT, Goss KU, Eisenreich SJ (1997) Sorption of nonionic, hydrophobic organic chemicals to mineral surfaces. Environ Sci Technol 31:1079-1086. https://doi.org/10.1021/es960606g
Marklein AR, Houlton BZ (2011) Nitrogen inputs accelerate phosphorus cycling rates across a wide variety of terrestrial ecosystems. New Phytol 193(3):696-704. https://doi.org/10.111 1/j.1469-8137.2011.03967.x

Naidu R, Rogers S, Gupta VVSR, Kookana RS, Bolan NS, Andriano D (2006) Bioavailability of heavy metals in the soil-plant environment and its potential role in risk assessment an over view. In: 4th international conference on the biogeochemistry of trace elements, pp 57-758. ISBN 1-57808-192-0

Ohta H, Hattori T (1980) Bacteria sensitive to nutrient broth medium in terrestrial environments. Soil Sci Plant Nutr 26:99-107. https ://doi.org/10.1080/00380768.1980.10433216

Oleszczuk P, Jośko I, Futa B, Pasieczna-Patkowska S, Pałys E, Kraska $P$ (2014) Effect of pesticides on microorganisms, enzymatic activity and plant in biochar-amended soil. Geoderma 214-215:10-18. https://doi.org/10.1016/j.geoderma.2013.10.010

Polacco JC, Mazzafera P, Tezotto T (2013) Opinion-nickel and urease in plants: still many knowledge gaps. Plant Sci 199-200:79-90. https://doi.org/10.1016/j.plantsci.2012.10.010

Raboni M, Viotti P, Capodaglio AG (2015) A comprehensive analysis of the current and future role of biofuels for transport in the European Union (EU). Rev Ambient Água. https://doi.org/10.4136/ ambi-agua. 1492

Ramirez KS, Craine JM, Fierer N (2012) Consistent effects of nitrogen amendments on soil microbial communities and processes across biomes. Glob Change Biol 18:1918e1927. https://doi.org/10.111 1/j.1365-2486.2012.02639.x

Rathnayake VN, Megharaj M, Bolan N, Naidu R (2010) Tolerance of heavy metals to gram positive soil bacteria. Int J Civ Environ Eng 2(4):191-195

Rodina A (1968) Microbiological water testing methods. PWRiL, Warsaw (in polish)

Różyło K, Oleszczuk P, Jośko I, Kraska P, Kwiecińska-Poppe E, Andruszczak S (2015) An ecotoxicological evaluation of soil fertilized with biogas residues or mining waste. Environ Sci Pollut Res 22(10):7833-7842. https://doi.org/10.15244/pjoes/85070

Różyło K, Świeca M, Gawlik-Dziki U, Andruszczak U, KwiecińskaPoppe E, Kraska P (2017) Phytochemical properties and heavy metal accumulation in wheat grain after three years' fertilization with biogas digestate and mineral waste. Agric Food Sci 26(3):148-159. https://doi.org/10.23986/afsci.63156

Shi B, Zhang J, Wang Ch, Ma J, Sun W (2018) Responses of hydrolytic enzyme activities in saline-alkaline soil to mixed inorganic and organic nitrogen addition. Sci Rep 8:4543. https://doi.org/10.1038/ s41598-018-22813-9

Smejkalova M, Mikanova O, Boruvka L (2003) Effects of heavy metals concentrations on biological activity of soil microorganisms. Plant Soil Environ 49:321-326

Stefaniuk M, Bartmiński P, Różyło K, Dębicki R, Oleszczuk P (2015) Ecotoxicological assessment of residues from different biogas production plants used as fertilizer for soil. J Hazard Mater 298:195202. https://doi.org/10.1016/j.jhazmat.2015.05.026

Subhani A, Changyong H, Zhengmiao X, Min L, Elghawry AM (2001) Impact of soil environment and agricultural practices on microbial/dehydrogenase enzyme activity in soil: a review. Pak J Biol Sci 4:333-338. https://doi.org/10.3923/pjbs.2001.333.338

Svensson K, Odlare M, Pell M (2004) The fertilizing effect of compost and biogas residues from source separated household waste. J Agric Sci 142:461-467. https://doi.org/10.1017/S002185960 4004514

Tabatabai MA, Bremner JM (1969) Use of p-nitrophenol phosphate for assay of soil phosphatase activity. Soil Biol Biochem 1:301-307. https://doi.org/10.1016/0038-0717(69)90012-1

Zantua MJ, Bremner JM (1975) Comparison of methods of assaying urease activity in soils. Soil Biol Biochem 7:291-295. https://doi. org/10.1016/0038-0717(75)90069-3 